\title{
Herpetofauna of protected areas in the Caatinga I: Raso da Catarina Ecological Station (Bahia, Brazil)
}

\author{
Adrian Antonio Garda ${ }^{1 *}$, Taís Borges Costa ${ }^{2}$, Carlos Roberto dos Santos-Silva ${ }^{3}$, Daniel Oliveira \\ Mesquita ${ }^{2}$, Renato Gomes Faria ${ }^{4}$, Breno Moura da Conceição ${ }^{4}$, Izabel Regina Soares da Silva ${ }^{4}$, \\ Anthony Santana Ferreira ${ }^{4}$, Stephanie Menezes Rocha ${ }^{4}$, Cristiane Nikely Silva Palmeira ${ }^{5}$, Ricardo \\ Rodrigues $^{2}$, Stephen Francis Ferrari ${ }^{3}$ and Selma Torquato ${ }^{5}$
}

1 Universidade Federal do Rio Grande do Norte, Centro de Biociências, Departamento de Botânica, Ecologia e Zoologia, Laboratório de Anfíbios e Répteis-LAR, Campus Universitário, Lagoa Nova, 59078-900, Natal, RN, Brazil.

2 Universidade Federal da Paraíba, Centro de Ciências Exatas e da Natureza, Departamento de Sistemática e Ecologia, Laboratório de Herpetologia, Cidade Universitária, 58059-000, João Pessoa, PB, Brazil.

3 Universidade Federal de Sergipe, Programa de Pós-graduação em Ecologia e Conservação (NPEC), Cidade Universitária, Av. Marechal Rondon, s/n, Jardim Rosa Elze, 49100-000, São Cristóvão, SE, Brazil.

4 Universidade Federal de Sergipe, Departamento de Biologia-DBI, Laboratório de Cordados (Herpetologia/Ictiologia), Cidade Universitária, Av Marechal Rondon, s/n, Jardim Rosa Elze, 49100-000, São Cristóvão, SE, Brazil.

5 Universidade Federal de Alagoas, Setor de Zoologia, Museu de História Natural, Av. Aristeu de Andrade 452, Farol, 57051-090, Maceió, AL, Brazil.

* Corresponding author:. E-mail pseudis@gmail.com

\begin{abstract}
We provide a list of amphibian and squamate species collected in the Raso da Catarina Ecological Station, Bahia state, Brazil, during two distinct periods. An initial visual inventory of amphibians was conducted monthly from March 2010 to February 2011, using transects in a forest and temporary ponds. The second inventory was conducted over a 30day period between March and April, 2012, when 37 pitfall trap arrays, each consisting of four buckets and supplementary glue traps, were set in low scrub and forest, complemented by opportunistic searches. A total of 19 lizard species, two amphisbaenians, 21 frogs, and 11 snakes were recorded during the study. New records for the protected area include 10 lizards, one amphisbaenian, 15 amphibians, and 11 snakes (36 species in total). Several species typical of the Atlantic Forest were collected, reflecting the potential influence of this biome, especially in the sampled forest habitats (Mata da Pororoca).
\end{abstract}

\section{INTRODUCTION}

The biodiversity of the semi-arid Caatinga morphoclimatic domain is poorly known, and it seems likely that the species richness of many groups is still greatly underestimated (Silva et al. 2005). For many years, the lack of data fuelled misconceptions about the biological diversity of this region, which included the idea that it was characterized by reduced species richness and endemism, and low levels of anthropogenic impact (Silva et al. 2004). Over the past few decades, however, advances in research have debunked these fallacies, and the Caatinga is now known to be the world's richest semiarid biome, characterized by high levels of endemism, but also widespread habitat degradation (Silva et al. 2005). Even so, Tabarelli and Vicente (2004) estimated that the biological diversity of approximately $40 \%$ of the total area of the biome is still completely unknown, and that much of the rest is still under-sampled.

While the understanding of the biome's herpetofauna is probably no better than that of other vertebrate groups, a total of 173 species have been recorded to date, including 47 lizards, 10 amphisbaenians, 52 snakes, 10 turtles, three crocodylians, 48 anurans, and three caecilians (Rodrigues 2003). Many other species are restricted to the upland enclaves of humid forest, known as brejos de altitude, and other habitat types which, if included in the analysis, would further increase the list of species.

Less than $1 \%$ of the Caatinga is currently protected by strict conservation units (Leal et al. 2005). Thirteen of these units - including the area of the present study - are federal protected areas, which cover a total area of 9920 $\mathrm{km}^{2}$, although some of these sites include considerable areas of Cerrado savanna, rather than Caatinga scrub. In addition to being small in both number and area, most of these units not only lack adequate infrastructure, but also face land tenure problems, and lack systematic biological inventories or even management plans. Independently of these problems, the current system is clearly inadequate to ensure the protection of the region's biodiversity, judging by the evaluation of plants (Tabarelli and Vicente 2004).

As part of a survey of strict protected areas in the Caatinga biome, which will include at least nine conservation units, the present study focuses on the Raso da Catarina Ecological Station in northeastern Bahia. The occurrence of amphibians and squamates within this protected area was recorded over a 30-day survey, with complementary data on the anuran fauna being collected during a one-year ecological study. The species richness of lizards and frogs recorded in the present study was compared with the data available for other localities in the Caatinga.

\section{Materials ANd Methods}

The present study focused on the Raso da Catarina Ecological Station (ESEC-RC), a 99,772 ha strict protected area in the São Francisco valley of northeastern Bahia, Brazil (ICMBio, 2008, Figure 1). The local climate is semi- 
arid, with a mean annual temperature of $27^{\circ} \mathrm{C}$ and rainfall of 500 to $800 \mathrm{~mm}$. The area is covered with deep, acidic, and sandy soils of low fertility and lacks perennial bodies of surface water. The topography is mostly flat, punctuated with sandstone outcrops (Figure 2A,B) reaching $400 \mathrm{~m}$ above sea level (Velloso et al. 2002). The vegetation is primarily composed of low Caatinga (caatinga baixa), a common physiognomy in areas of sandy soils (Prado 2003).

Two separate inventories were conducted, the first exclusively for anuran amphibians with monthly field visits from March 2010 to February 2011, and the second for all herpetofauna. For the amphibian inventory, frogs were sampled along a transect in Caatinga forest (Figure 2E, 0953'04.6"S, 38³9'51.5" W, $469 \mathrm{~m}$ asl) and at a temporary pond (Figure 2F, $09^{\circ} 55^{\prime} 1.00^{\prime \prime} \mathrm{S}, 38^{\circ} 41^{\prime} 55.6^{\prime \prime} \mathrm{W}$, $457 \mathrm{~m}$ asl), in the western sector of the protected area, in the municipality of Jeremoabo. These surveys involved three distinct approaches, following Heyer et al. (1994): a) Surveys at breeding sites, which involve walking along the edge of bodies of water recording all species through direct observation (visual search) and indirect evidence (advertisement calls); b) Visual encounter surveys, which involve searching the varied microhabitats (above rocks, on fallen logs, on bromeliads, etc.) occupied by frogs in areas away from water; c) Audio strip transects, during which a $1 \mathrm{~km}$ transect is walked and species are recorded based on advertisement calls. Each site was sampled for two nights per month, and during each night three collectors conducted surveys during a continuous 6-hour period (18:00 h to $24: 00 \mathrm{~h}$ ), resulting in a total sampling effort of 18 person-hours per night.

For the herpetological survey, between March 30th and April 27th, 2012, 37 pitfall traps were installed along four trails located within the municipality of Paulo Afonso: three near the main protected area base (9 ${ }^{\circ} 43^{\prime} 53.67^{\prime \prime} \mathrm{S}$, $38^{\circ} 40^{\prime} 58.24^{\prime \prime} \mathrm{W}, 603 \mathrm{~m}$ asl), representing the typical low Caatinga vegetation, and one in an area of Caatinga forest (Mata da Pororoca: 948'29.0"S, 38²9'32.04"W, $701 \mathrm{~m}$

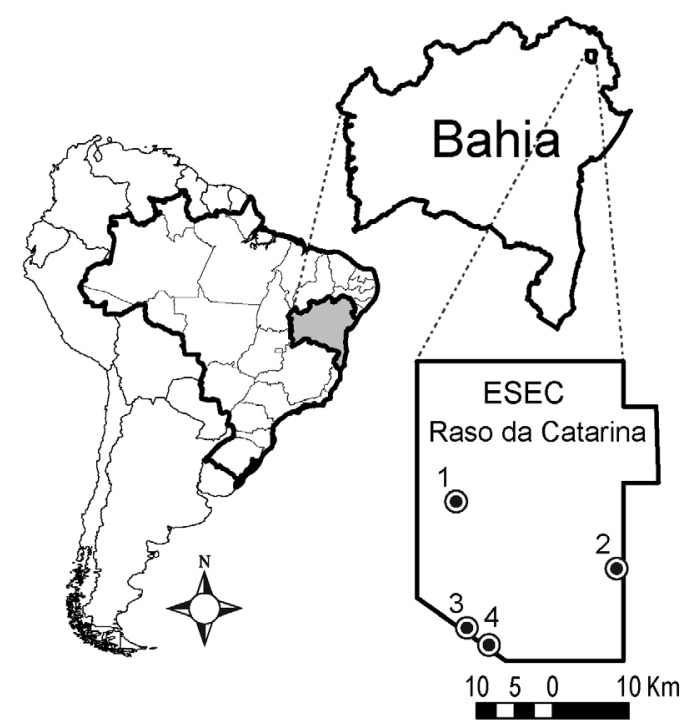

FigurE 1. Location of the Raso da Catarina Ecological Station in the State of Bahia, Brazil. Four sampling localities are labeled: 1) Protected area Base, 2) Mata da Pororoca, 3) Temporary pond, and 4) Transect in Caatinga forest; 3 and 4 were used exclusively for amphibian inventories. See Methods for coordinates and elevations. asl). The traps were composed of four $30 \mathrm{~L}$ buckets set in the ground in a Y shape, with one central bucket and one at each extremity, connected by three $6 \mathrm{~m}$ drift fences built with plastic sheets. At each pitfall, four glue traps were set, two on the ground, and two on branches in the vegetation ( $1 \mathrm{~m}$ above ground). Pitfall traps were checked daily to ensure animals did not escape traps or die in the traps. Additional qualitative searches were also conducted along existing trails within the study area by five to 11 herpetologists.

Voucher specimens were euthanized with lidocaine (applied to the abdomen of frogs or injected in lizards and snakes), preserved in $10 \%$ formalin and stored in $70 \%$ ethanol. Specimen collection was authorized through federal permits issued to AAG (SISBIO \# 32527-1), CRSS (SISBIO \#22094), and TBC (SISBIO \# 29550-2). Voucher specimens were deposited in the herpetological collection of the Federal University of Paraíba (CHUFPB), collection of the Laboratory of Amphibians and Reptiles at the Federal University of Rio Grande do Norte (CLAR-UFRN), and Museu de Zoologia da Universidade Estadual de Feira de Santana (MZUEFS). Catalog numbers for each specimen are listed in Table 1.

Species richness sampling efficiency was evaluated based on rarefaction curves for the data on the number of individual lizards, frogs, and all groups combined (Gotelli and Colwell 2001), using EstimateS 8.2.0 (Colwell 1994). The curves were obtained through 1000 resamplings of the original data, with no reposition.

\section{RESULTS AND DisCuSSION}

We collected 19 lizard species, two amphisbaenians, 11 snakes, and 21 frogs (Table 1, Figures 3-8). Of these, 10 lizard species, one amphisbaenian, 11 snakes, and 15 frogs were recorded in the ESEC-RC for the first time.

Only the rarefaction curve for amphibians reached the asymptote (Figure 9). While an especially large number of specimens of lizards were captured - approximately 500 - the species curve for this group was still rising at the end of the study, indicating that additional species would be recorded if a much larger sample of specimens was collected (Figure 9).

The species richness recorded for lizards in the present study was one of the highest reported to date for any Caatinga site. At 15 sites in Pernambuco (Moura et al. 2010b), for example, only two - Catimbau National Park and Exu - had an equivalent number of lizard species (18 at both sites) to that recorded at ESEC-RC. This may reflect the positive effects of the establishment of protected areas (in the case of Catimbau and ESEC-RC) on the diversity of habitats and fauna, although differences in sampling effort and techniques may also be a factor. The fact that the considerable sampling effort deployed in the present study was insufficient for the sampling curve to reach the asymptote indicates that sampling error, while widelyrecognized for the Caatinga, may still be underestimated in general. This is further reinforced by the fact that the diversity of the lizard fauna found in some very well studied areas, such as the municipality of Exu in Pernambuco (Vitt 1995), may be quite distinct, and may thus require even more extensive sampling efforts in order to guarantee the recording of the full species richness. 
At least one potentially undescribed species was collected (Cnemidophorus aff. nigrigula) during this study. While this whiptail lizard appears to be related to the recently described C. nigrigula (Arias et al. 2011), the uniform coloration pattern of the specimens from ESEC$\mathrm{RC}$ is distinct from that of the species description.

One characteristic of the fauna of this site is a marked affinity with that of the Atlantic Forest, including typical species of this more humid biome, such as Coleodactylus meridionalis and Ischnocnema ramagii. As might be expected, the lizard $C$. meridionalis was only recorded in the Pororoca forest, an enclave of more humid habitat, which is protected almost entirely by the ESEC-RC. The findings of the present study support the incorporation of the remaining parts of this habitat within the ESEC-RC.

With the present study, the known local diversity of amphibians reached a total of 21 species (Table 1 ). While a severe droughtaffected the region during theherpetological survey, $70 \%$ of the amphibian species recorded during the amphibian inventory were reconfirmed during this period. This nevertheless appears to be one of the highest levels of amphibian diversity recorded anywhere in the Caatinga, second only to Catimbau National Park and Fazenda Saco, both in Pernambuco, where 23 species have been recorded
(Moura et al. 2010a). Higher numbers of species may only be found in ecotonal areas that are under the influence of neighboring Atlantic Forest ecosystems (Magalhães et al. 2013).

The number of amphibian species recorded in the present study is surprising, given the absence of permanent water bodies within the ESEC-RC. The results of this study also indicate that many other Caatinga areas may be undersampled, given the marked unpredictability of rainfall patterns in this environment (Rodrigues 2003). The lack of records of some widespread Caatinga species such as Leptodactylus fuscus - in the ESEC-RC suggests that the confirmed number of species may be an underestimate of the total diversity of this protected area, even though the rarefaction curve for amphibians seems to have reached a plateau.

Given the extension of the protected area and the heterogeneity of habitats within the ESEC-RC, future research must focus primarily on areas not sampled in the present study. In particular, inventories of amphibians should also include the collection of larvae, which may help identify elusive species (da Silva 2010). In particular, the diversity of the snake fauna of the study area appears to have been underestimated considerably.
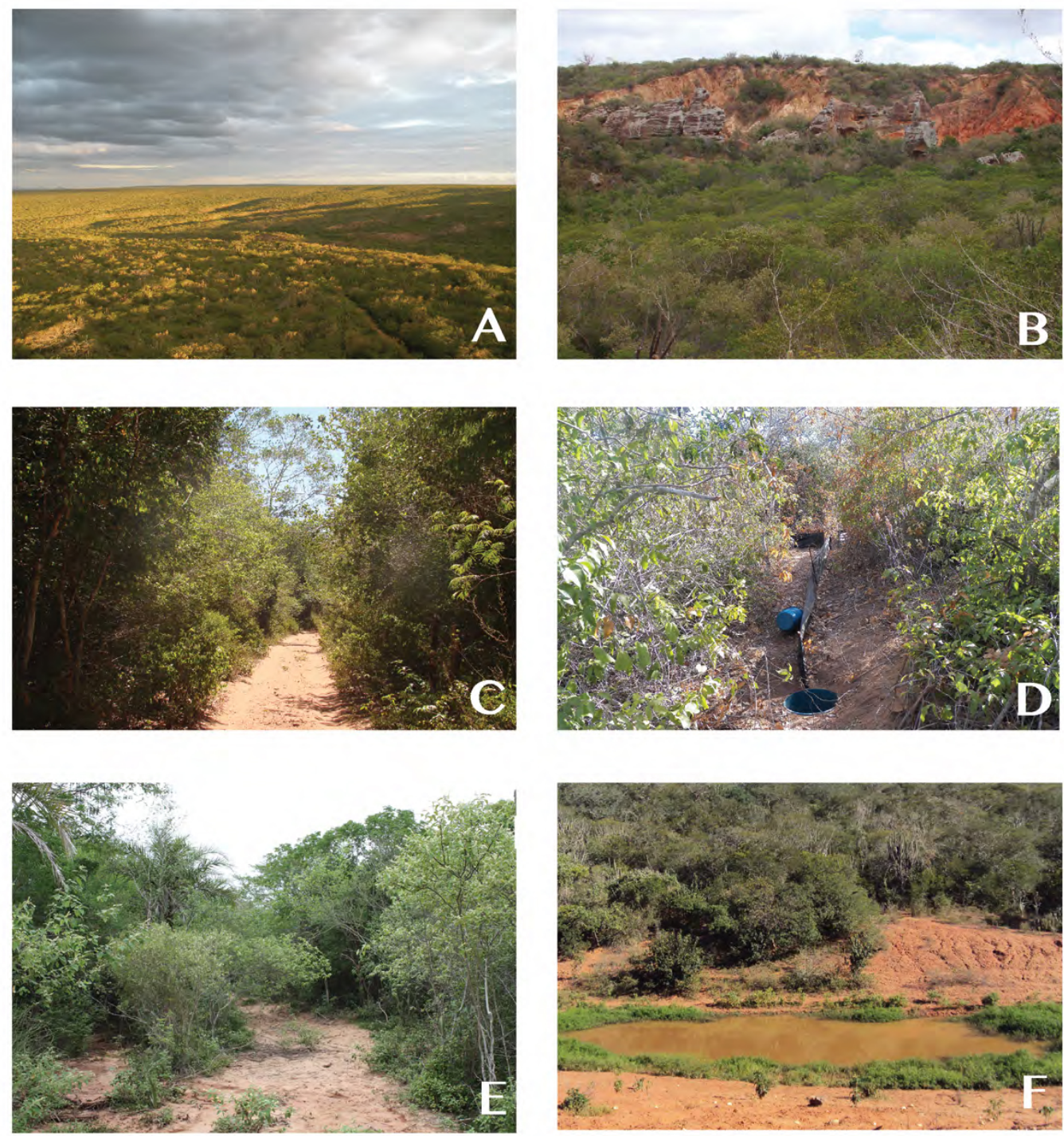

FIGURE 2. Habitats sampled during the amphibian and the herpetological survey at the Raso da Catarina Ecological Station (ESEC-RC), Bahia State, Brazil. A) Overview of the Caatinga shrub around the protected area Base; B) Rocky outcrops, C) Mata da Pororoca, D) pitfall trap in the low Caatinga near the Base, E) transect in Caatinga forest used for amphibian inventory, F) temporary pond used for amphibian inventory. 
TABLE 1. List of squamates and anuran amphibians recorded in the present study at the Raso da Catarina Ecological Station (ESEC-RC), Bahia, Brazil.

\begin{tabular}{|c|c|c|c|c|}
\hline & FAMILY & SPECIES & SOURCE & VOUCHER \\
\hline \multicolumn{5}{|c|}{ Lizards and Amphisbaenids } \\
\hline 1 & Amphisbaenidae & Amphisbaena alba & present study & AAGARDA4617 \\
\hline 2 & & A. arenaria & present study, (ICMBIO 2008) & AAGARDA4050 \\
\hline 3 & Gekkonidae & Gymnodactylus geckoides & present study, (ICMBIO 2008) & AAGARDA4081 \\
\hline 4 & & Hemidactylus brasilianus & present study, (ICMBIO 2008) & AAGARDA4080 \\
\hline 5 & Gymnophthalmidae & Acratosaura mentalis & present study & AAGARDA4125 \\
\hline 6 & & Anotosaura vanzolinia & present study & AAGARDA4073 \\
\hline 7 & & Psilophthalmus paeminosus & present study & AAGARDA4309 \\
\hline 8 & Iguanidae & Iguana iguana & present study & AAGARDA4207 \\
\hline 9 & Leiosauridae & Enyalius bibronii & present study & AAGARDA4070 \\
\hline 10 & Phyllodactylidae & Lygodactylus klugei & present study, (ICMBIO 2008) & AAGARDA4508 \\
\hline 11 & & Phyllopezus pollicaris & present study, (ICMBIO 2008) & AAGARDA4084 \\
\hline 12 & Polychrotidae & Polychrus acutirostris & present study, (ICMBIO 2008) & AAGARDA4616 \\
\hline 13 & Scincidae & Mabuya heathi & present study & AAGARDA4074 \\
\hline 14 & & M. macrorhyncha & present study, (ICMBIO 2008) & AAGARDA4043 \\
\hline 15 & Sphaerodactylidae & Coleodactylus meridionalis & present study & AAGARDA4145 \\
\hline 16 & Teiidae & Ameiva ameiva & present study & AAGARDA4393 \\
\hline 17 & & Cnemidophorus aff. nigrigula & present study & AAGARDA4044 \\
\hline 18 & & Tupinambis merianae & present study & AAGARDA4294 \\
\hline 19 & Tropiduridae & Tropidurus cocorobensis & present study, (ICMBIO 2008) & AAGARDA4041 \\
\hline 20 & & T. hispidus & present study, (ICMBIO 2008) & AAGARDA4064 \\
\hline 21 & & T. semitaeniatus & present study, (ICMBIO 2008) & AAGARDA4071 \\
\hline \multicolumn{5}{|c|}{ Anurans } \\
\hline 1 & Bufonidae & Rhinella granulosa & present study, (ICMBIO 2008) & AAGARDA4154 \\
\hline 2 & & R. jimi & present study & AAGARDA4384 \\
\hline 3 & Brachycephalidae & Iscnocnema ramagii & present study, (ICMBIO 2008) & MZUEFS3719 \\
\hline 4 & Cycloramphidae & Proceratophrys cristiceps & (ICMBIO 2008) & \\
\hline 5 & Hylidae & Dendropsophus gr. microcephalus & present study & MZUEFS3718 \\
\hline 6 & & D. novaisi & present study & MZUEFS3737 \\
\hline 7 & & D. oliveirai & present study & MZUEFS3715 \\
\hline 9 & & D. soaresi & present study & MZUEFS3729 \\
\hline 10 & & Hypsiboas crepitans & present study & AAGARDA4150 \\
\hline 11 & & Phyllomedusa bahiana & present study & AAGARDA4146 \\
\hline 12 & & P. nordestina & present study & MZUEFS3713 \\
\hline 13 & & Scinax $x$-signatus & present study & AAGARDA4049 \\
\hline 14 & & S. pachycrus & present study & MZUEFS3722 \\
\hline 15 & & Trachycephalus atlas & present study, (Santos-Silva et al. 2012) & MZUEFS3727 \\
\hline 16 & Leptodactylidae & Leptodactylus macrosternum & present study & AAGARDA4147 \\
\hline 17 & & L. troglodytes & present study, (ICMBIO 2008) & AAGARDA4285 \\
\hline 18 & & Physalaemus cicada & present study & AAGARDA4214 \\
\hline 19 & & P. kroyeri & present study & AAGARDA4216 \\
\hline 20 & & Pleurodema diplolister & (ICMBIO 2008) & \\
\hline 21 & Microhylidae & Dermatonotus muelleri & present study & AAGARDA4409 \\
\hline \multicolumn{5}{|c|}{ Snakes } \\
\hline 1 & Typhlopidae & Typhlops cf. yonenagae & present study & AAGARDA4684 \\
\hline 2 & Boidae & Boa constrictor & present study & AAGARDA4317 \\
\hline 3 & & Epicrates assisi & present study & AAGARDA4618 \\
\hline 4 & Colubridae & Chironius bicarinatus & present study & AAGARDA4636 \\
\hline 5 & & Oxybelis aeneus & present study & AAGARDA4665 \\
\hline 6 & & Spilotes pullatus & present study & AAGARDA4681 \\
\hline 7 & & Tantilla melanocephala & present study & AAGARDA4674 \\
\hline 8 & Dipsadidae & Leptodeira annulata & present study & AAGARDA4391 \\
\hline 9 & & Oxyrhopus trigeminus & present study & AAGARDA4392 \\
\hline 10 & & Taeniophalus occipitalis & present study & AAGARDA4129 \\
\hline 11 & Viperidae & Bothrops erythromelas & present study & AAGARDA4115 \\
\hline
\end{tabular}



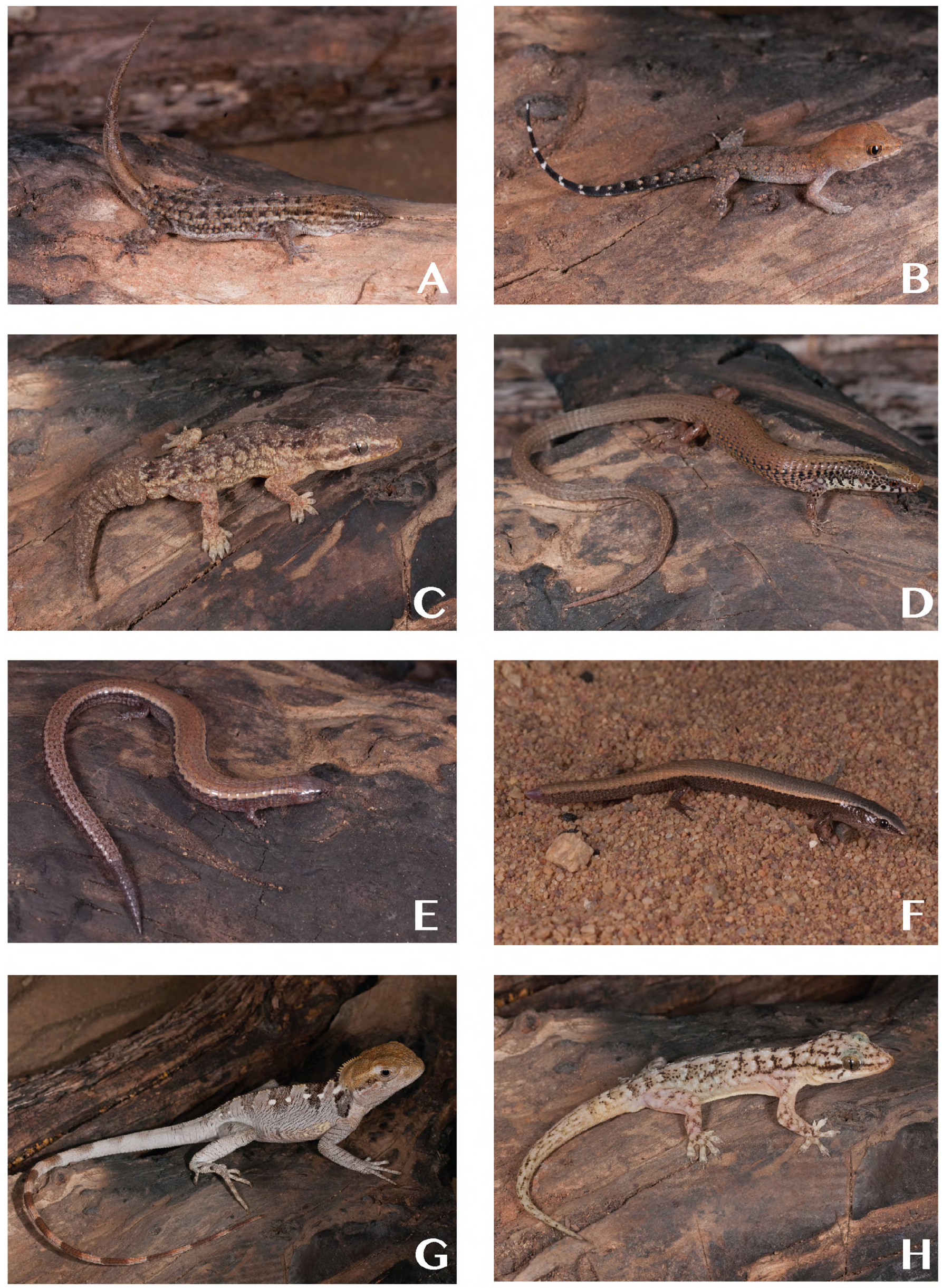

FIGURE 3. Lizard species collected in the Raso da Catarina Ecological Station (ESEC-RC), Bahia, Brazil. Gekkonidae: A, B) Gymnodactylus geckoides and C) Hemidactylus brasilianus. Gymnophthalmidae: D) Acratosaura mentalis, E) Anotosaura vanzolinia, F) Psilophthalmus paeminosus. Leiosauridae: G) Enyalius bibronii. Phyllodactylidae: H) Phyllopezus pollicaris. 

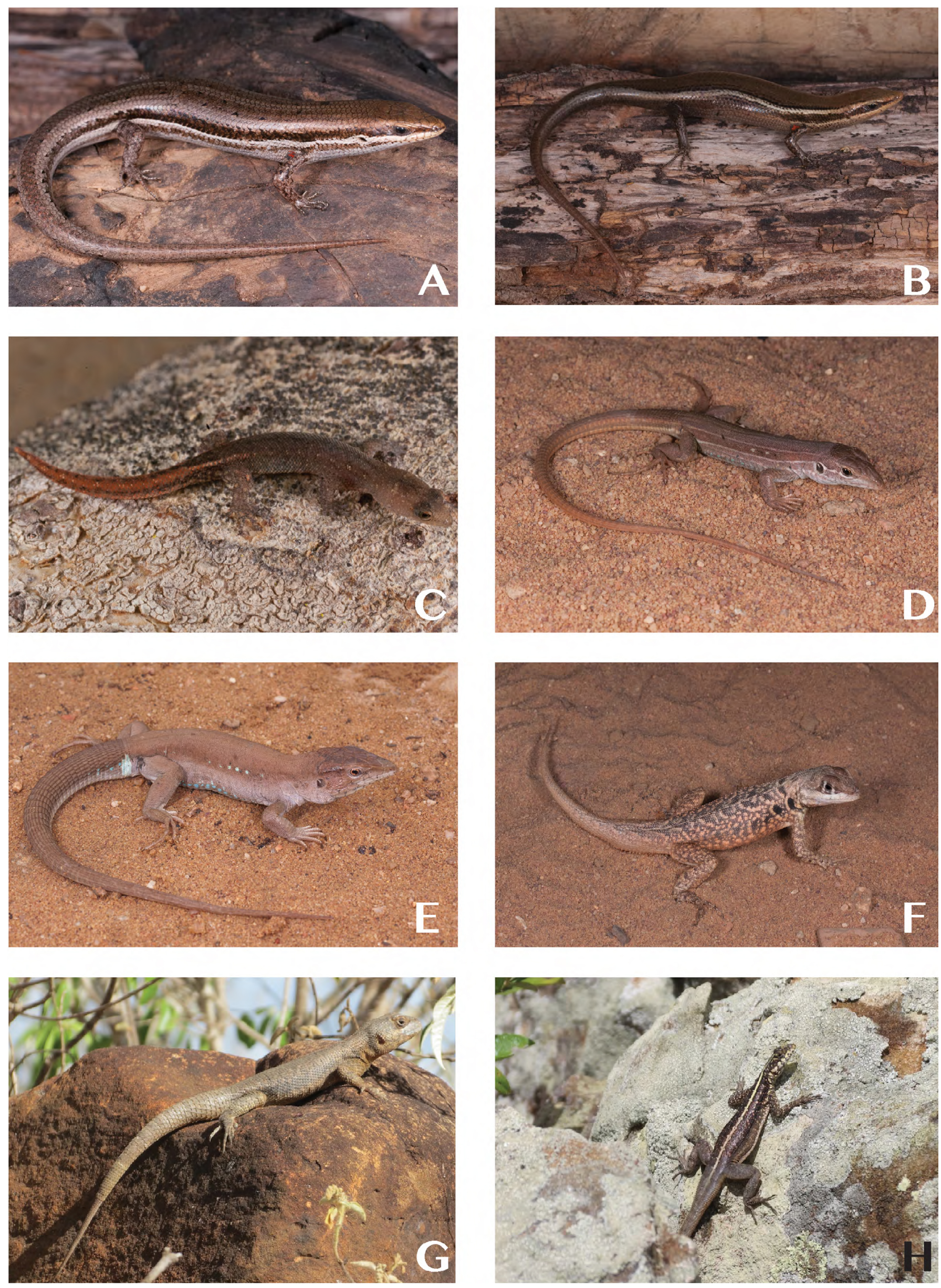

FigURE 4. Lizard species collected in the Raso da Catarina Ecological Station (ESEC-RC), Bahia, Brazil. Scincidae: A) Mabuya heathi, B) Mabuya macrorhyncha. Sphaerodactylidae: C) Coleodactylus meridionalis. Teiidae: D, E) Cnemidophorus aff. nigrigula. Tropiduridae: F) Tropidurus cocorobensis, G) T. hispidus, H) T. semitaeniatus. 

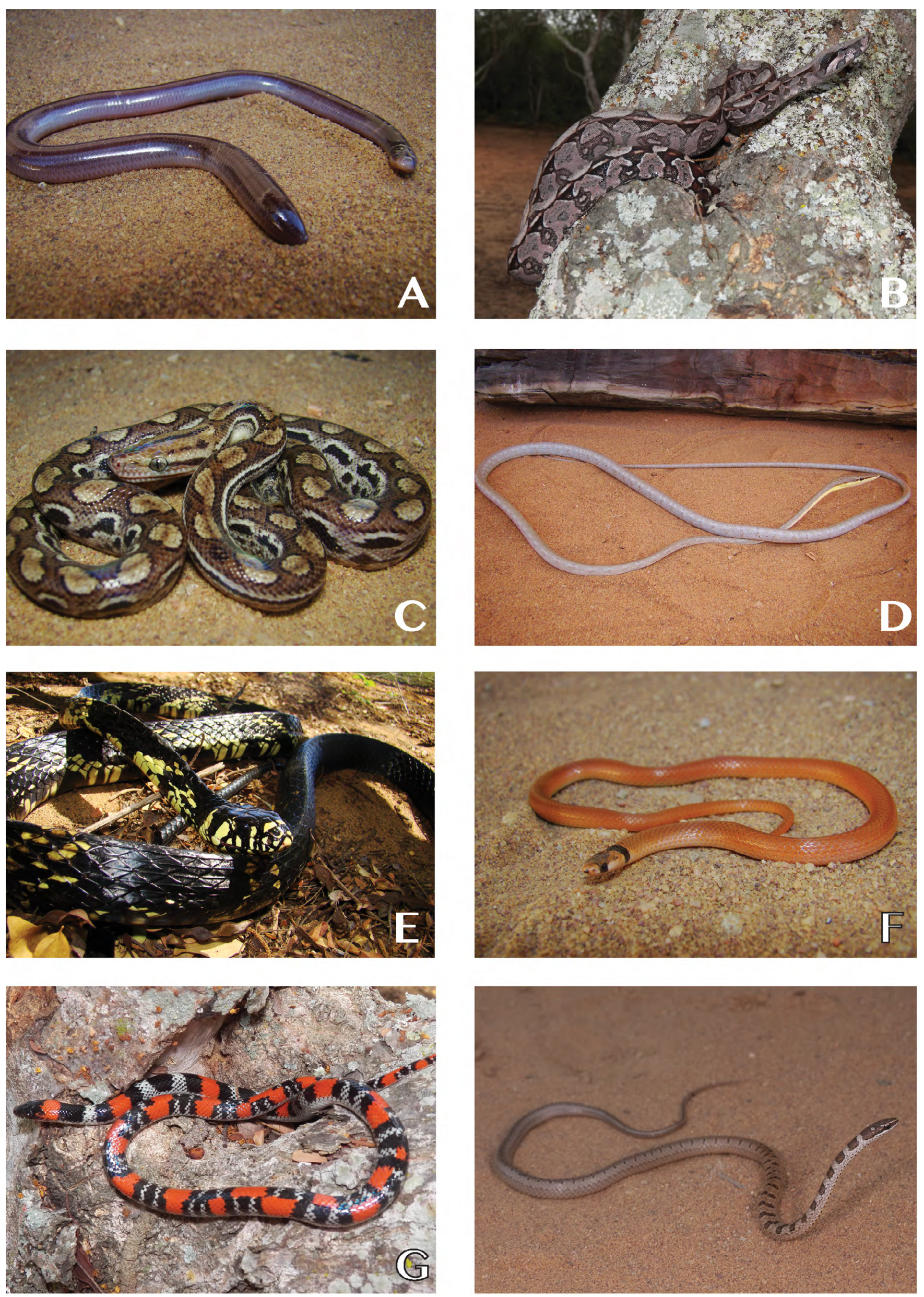

FIGURE 5. Snake species collected in the Raso da Catarina Ecological Station (ESEC-RC), Bahia, Brazil. Typhlopidae: A) Typhlops cf. yonenagae. Boidae: B) Boa constrictor, C) Epicrates assisi. Colubridae: D) Oxybelis aeneus, E) Spilotes pullatus, F) Tantilla melanocephala. Dipsadidae: G) Oxyrhopus trigeminus, H) Taeniophalus occipitalis. 

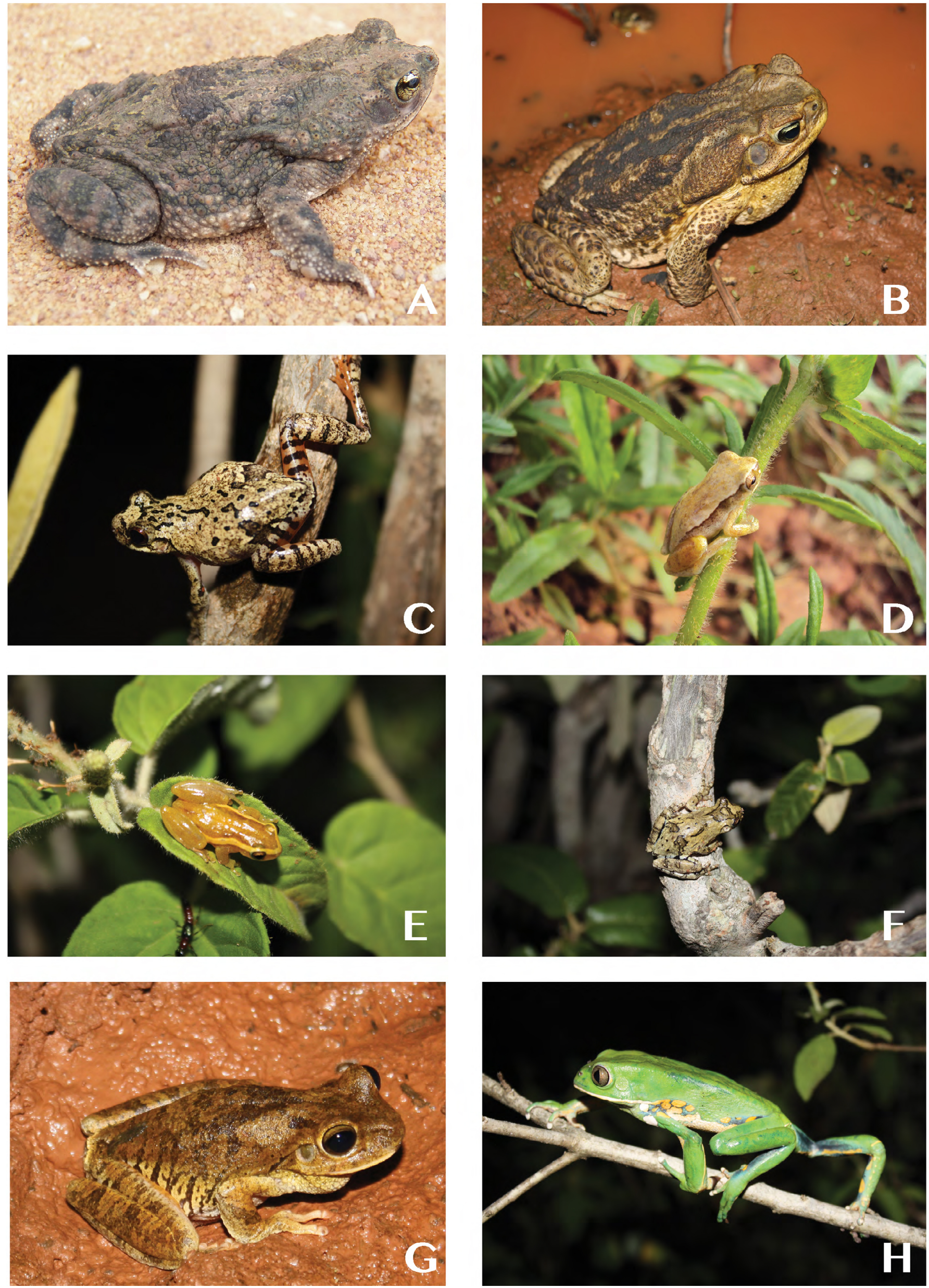

FIGURE 6. Frog species collected in the Raso da Catarina Ecological Station (ESEC-RC), Bahia, Brazil. Bufonidae: A) Rhinella granulosa, B) R. jimi. Hylidae: C) Dendropsophus novaisi, D) D. cf. microcephalus, E) D. oliveirai, F) D. soaresi, G) Hypsiboas crepitans, H) Phyllomedusa bahiana. 

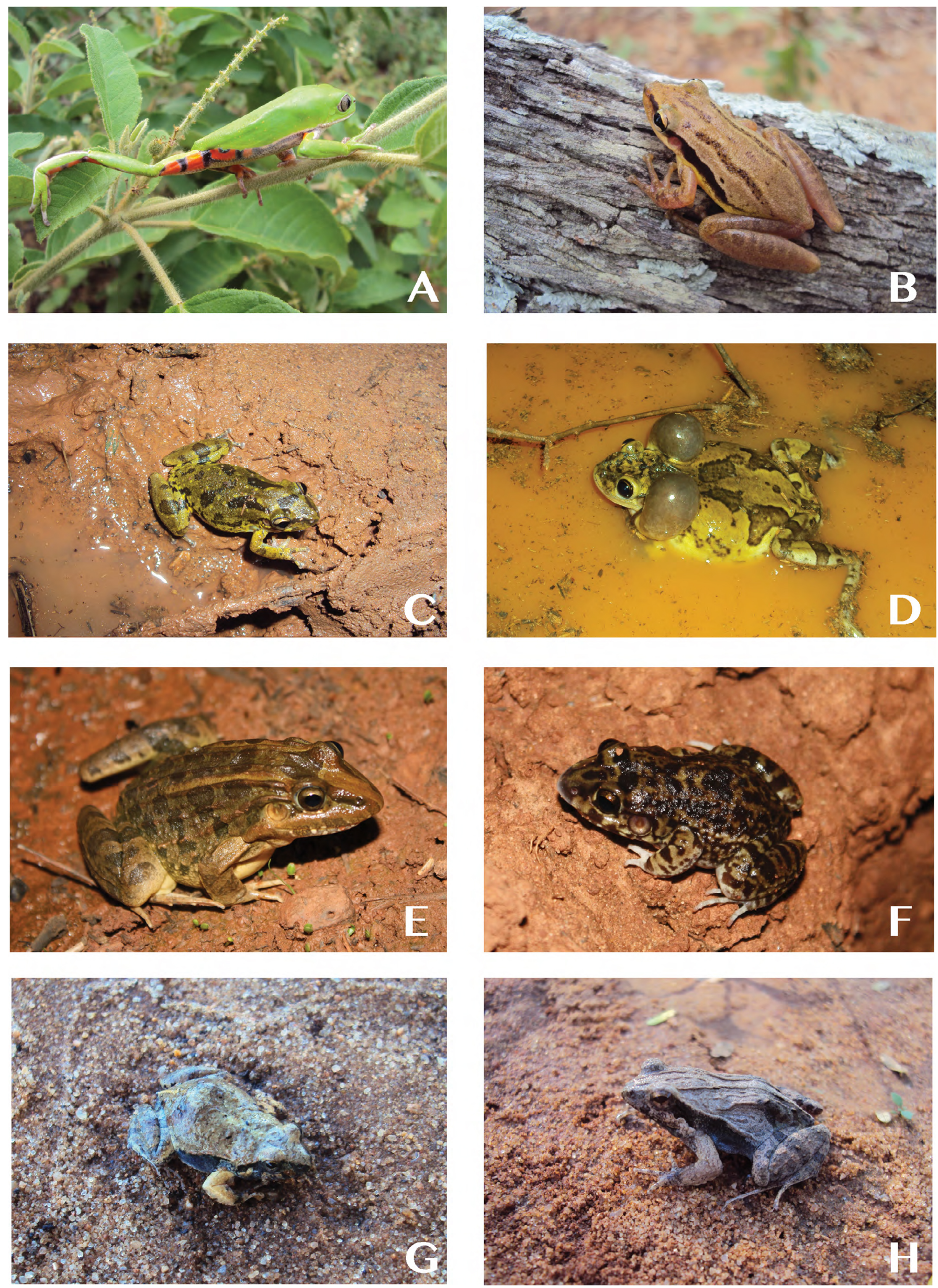

Figure 7. Frog species collected in the Raso da Catarina Ecological Station (ESEC-RC), Bahia, Brazil. Hylidae: A) Phyllomedusa nordestina, B) Scinax pachycrus, C) S. x-signatus, D) Trachycephalus atlas, Leptodactylidae: E) Leptodactylus macrosternum, F) L. troglodytes, G) Physalaemus cicada, H) P. kroyeri. 


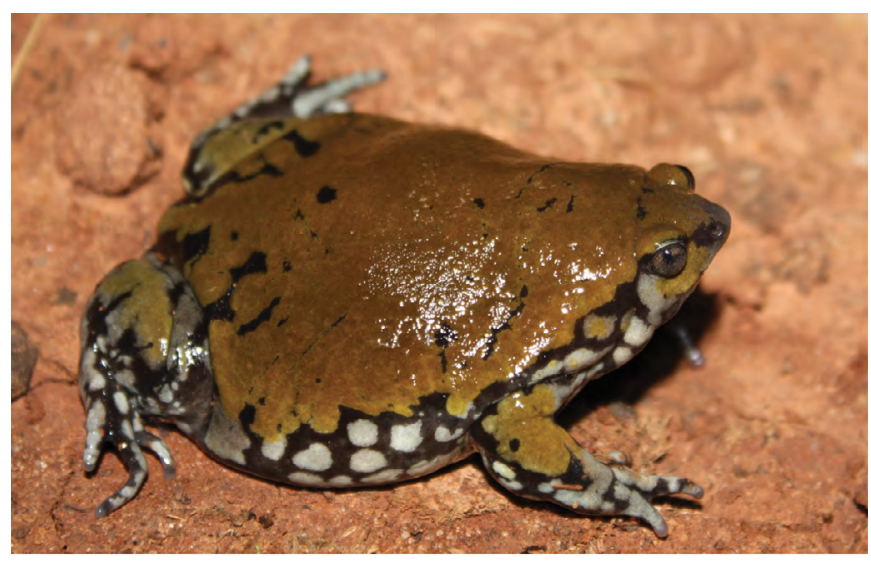

FIGURE 8. Frog species collected in the Raso da Catarina Ecological Station (ESEC-RC), Bahia, Brazil. Microhylidae: Dermatonotus muelleri.

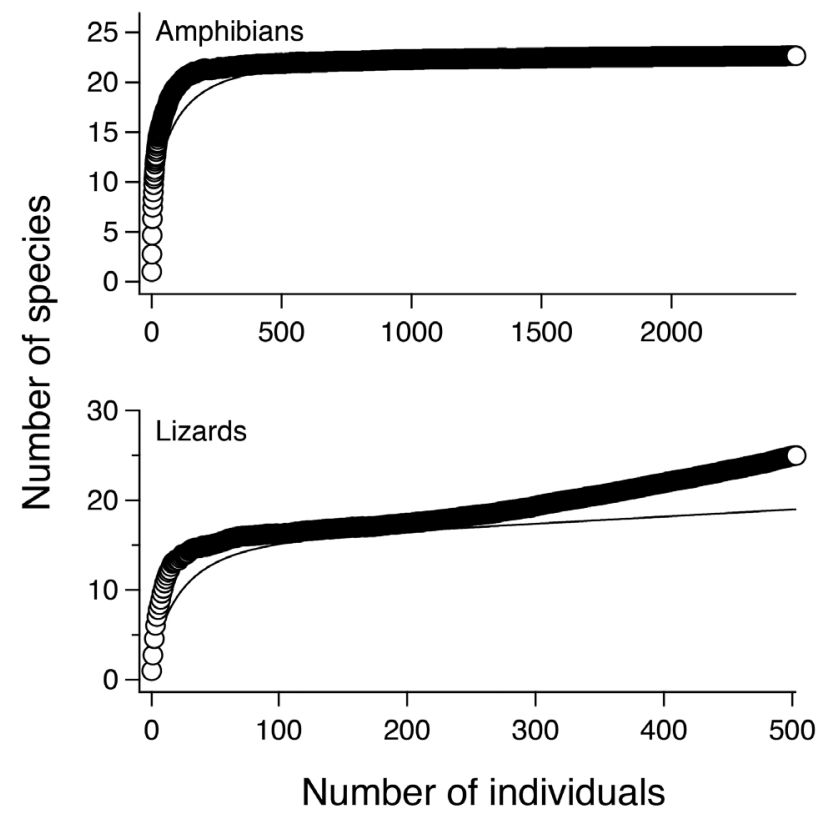

FIGURE 9. Species accumulation curves (lines) and rarefaction curves (circles) for lizards and amphibians based on the number of individual specimens recorded at the Raso da Catarina Ecological Station (ESECRC), Bahia, Brazil.

ACKNowledgments: We thank V. São Pedro and M. Henrique de Queiroz, for their assistance during fieldwork, and M. Bruzzi Lion for the map of the area. We are indebted to all the staff at the "Estação Ecológica do Raso da Catarina", especially E. Sousa and J. Tiago for logistic support during fieldwork. This study was partially supported by a grant from $\mathrm{CNPq} / \mathrm{ICMBio}$ to $\mathrm{AAG}$ entitled "Representatividade da Herpetofauna em Unidades de Conservação da Caatinga: Diversidade, Filogeografia e Relações com Biomas não Florestais Brasileiros" (process \# 552031/2011-9), as well as a CAPES scholarship to CRSS, and a CNPq research grant to SFF (303994/2011-8).

\section{Literature Cited}

Arias, F., C.M. De Carvalho, M.T. Rodrigues and H. Zaher. 2011. Two new species of Cnemidophorus (Squamata: Teiidae) of the C. ocellifer group, from Bahia, Brazil. Zootaxa(3022): 1-21.

Colwell, R.K. 1994. EstimateS: statistical estimation of species richness and shared species from samples. http://viceroy.eeb.uconn.edu/ estimates. Captured on 11 October 2012.

da Silva, F.R. 2010. Evaluation of survey methods for sampling anuran species richness in the Neotropics. South American Journal of Herpetology 5 (3): 212-220.

Gotelli, N.J. and R.K. Colwell. 2001. Quantifying biodiversity: procedures and pitfalls in the measurement and comparison of species richness. Ecology Letters 4 (4): 379-391.

Heyer, W.R., M.A. Donnelly, R.W. McDiarmid, L.-A.C. Hayek and M.S. Foster. 1994. Measuring and Monitoring Biological Diversity: Standard Methods for Amphibians. Washington: Smithsonian Institution Press. $364 \mathrm{p}$.

ICMBIO. 2008. Plano de Manejo Estação Ecológica Raso da Catarina. Brasília: Ministério do Meio Ambiente. 326 p.

Leal, I.R., J.M.C. Silva, M. Tabarelli and T.E. Lacher Jr. 2005. Mudando o curso da conservação da biodiversidade na Caatinga do Nordeste do Brasil. Megadiversidade 1 (1): 139-146.

Magalhães, F.M., A.K.B.P. Dantas, M.R.M. Brito, P.H.S. Medeiros, A.F. Oliveira, T.C.S.O. Pereira, M.H.C. Queiroz, D.J. Santana, W.P. Silva and A.A. Garda. 2013. Anurans from an Atlantic Forest-Caatinga ecotone in Rio Grande do Norte State, Brazil. Herpetology Notes 6: 1-10.

Moura, G.J.B., E.M. dos Santos, M.A.B. de Oliveira and M.C.C. Cabral. 2010a. Herpetofauna no Estado de Pernambuco. Brasília: Instituto Brasileiro do Meio Ambiente e dos Recursos Naturais Renováveis. 441 p.

Moura, G.J.B., E.M.X. Freire, E.M. Santos, Z.M.B. Morais, E.A.M. Lins, E.V.E. Andrade and J.D.C. Ferreira. 2010b. Distribuição Geográfica e Caracterização Ecológica dos Répteis do Estado de Pernambuco; p. 227-288 In: Moura, G.J.B., Santos, E.M., Oliveira, M.A.B. and Cabral, M.C.C. (ed.) Herpetofauna no Estado de Pernambuco. Brasília, DF: Ministério do Meio Ambiente.

Prado, D.E. 2003. As Caatingas da América do Sul; p. 3-73 In I.R. Leal, M. Tabarelli, and J.M.C. Silva (ed.) Ecologia e Conservação da Caatinga. Recife, PE: Editora Universitária UFPE.

Rodrigues, M.T. 2003. Herpetofauna da Caatinga; p. 181-236 In I.R. Leal, M. Tabarelli, and J.M.C. Silva (ed.) Ecologia e Conservação da Caatinga. Recife, PE: Editora Universitária UFPE.

Santos-Silva, C.R., S.F. Ferrari and F.A. Juncá. 2012. Acoustic characteristics of the advertisement call of Trachycephalus atlas Bokermann, 1966 (Anura: Hylidae). Zootaxa 3424: 66-68.

Silva, J.M.C., M. Tabarelli, M.T. Fonseca and L.V. Lins. 2004. Biodiversidade da Caatinga: Áreas e Ações Prioritárias Para a Conservação. Recife e Brasília: Universidade Federal de Pernambuco and Ministério do Meio Ambiente. $382 \mathrm{p}$

Silva, R.A., A.M.M. Santos and M. Tabarelli. 2005. Riqueza e Diversidade de Plantas Lenhosas em Cinco Unidades de Paisagem da Caatinga; p. 337-365 In I.R. Leal, M. Tabarelli, and J.M.C. Silva (ed.) Ecologia e Conservação da Caatinga. Recife, PE: Editora Universitária UFPE.

Tabarelli, M. and A. Vicente. 2004. Conhecimento Sobre Plantas Lenhosas da Caatinga: Lacunas Geográficas e Ecológicas; p. 101-111 In: Silva, J.M.C., Tabarelli, M., Fonseca, M.T. and Lins, L.V. (ed.) Biodiversidade da Caatinga: Áreas e Ações Prioritárias Para a Conservação. Brasília: Ministério do Meio Ambiente.

Velloso, A.L., E.V.S.B. Sampaio and F.G.S. Pareyn. 2002. Ecorregiões Propostas Para o Bioma Caatinga. Instituto de Conservação Ambiental The Nature Conservancy do Brasil. 76 p.

Vitt, L.J. 1995. The ecology of tropical lizards in the Caatinga of northeast Brazil. Occasional Papers of the Oklahoma Museum of Natural History 1 (1995): 1-29.

RECEIVED: August 2012

ACCEPTED: February 2013

Published ONLINE: April 2013

EDITORIAL RESPONSIBILITY: Ross MacCulloch 